\title{
An Exploration of the Concept and Practice of Co-teaching in Public Secondary School EFL Classes in Benin
}

\author{
Sekoubaou, Abel, Gbènakpon \\ University of Abomey-Calavi, Ecole Doctorale Pluridisciplinaire, "Espaces, Cultures et Développement”, Etudes \\ Anglophones. Cotonou, Benin
}

\begin{abstract}
Across Asia, in countries such as Japan, Korea, Taiwan, China, and Hong Kong, the practice of the Co- teaching model within English as a Foreign Language (EFL) classrooms has proved beneficial for both educators and learners. In those countries, having both native and non-native EFL teachers to develop and carry out lesson plans offers a great opportunity to build local teachers' capacities and promote cultural exchange between teachers and within the classroom. For learners, the co-teaching model gives the possibility to hear pronunciation, as well as tones and rhythm, of a native speaker in English. While researchers have noted the benefits of this strategic approach in both teaching and learning English as a foreign language, in those aforementioned Asian countries, they have failed to specify if the practice can be generalized to other EFL countries around the world. To my knowledge, no research has been conducted on co-teaching in Benin. To fill this gap, this study, through qualitative and quantitative methods, aims to shed light on the prospects and challenges of co-teaching in Beninese secondary schools. As the co-teaching practice in Benin is only done by US Peace Corps TEFL Volunteers, the target population has consisted of thirty of them and forty of their counterparts. Valuable data has been collected through class observations, interviews and questionnaires over a six-month period. The findings have shown that even though there are challenges, the approach of coteaching used in Benin is beneficial to both the team teachers and their learners. Finally, the study suggests ways to maximize the benefits of co-teaching and a few strategies to cope with challenges.
\end{abstract}

Index Terms - Co-teaching, US Peace Corps, TEFL Volunteers, Beninese secondary schools

\section{INTRODUCTION}

Teaching is the process of causing others to acquire knowledge or skill (Webster's New Collegiate dictionary 1961); this definition was updated by Smith (2016) who stated that teaching is "the process of attending to people's needs, experiences and feelings, and making specific interventions to help them learn particular things." Relating that definition to language teaching means bringing out the talent of language capacity in individuals, and taking into account their needs and experiences. People learn foreign languages based on their own needs as well as the opportunities that the various languages offer. The ultimate goal of learning a language is to use it for communication (Sekoubaou, 2017). English imposes itself as the medium for 80 per cent of the information stored in the world's computers; it is the official voice of the air, of the sea, and of Christianity (Montgomery, Alamou, Dago, Gueye \& Koffi 1995). As English is invaluable to millions of people around the world, it is taught and learned either as the mother tongue or as a foreign language. There is a need for professionals to teach English and the demand is constantly increasing. To succeed in such a complex profession requires solid trainings. English teachers need to be trained on how to effectively carry out their job and be dedicated and willing to update their knowledge and skills frequently as the language, and instruction of it, is dynamic - ever changing with - new concepts, new vocabulary, and new methodology. There are many ways through which people learn how to teach; however, in most of the teacher education programmes, classroom teaching practice stands as one of the pedagogical and didactic approaches used.

In the profession of teaching EFL, teachers may be a Native English- Speaking Teacher (NEST) or a Non-Native English-Speaking Teacher (NNEST). Whatever the case, English teachers adopt various teaching approaches; they may teach alone, which is the traditional language teaching approach, while others may co-teach. The latter approach is the new growing trend in many EFL countries. Having local teachers and native English- speaking teachers co-plan and coteach in EFL classes presents not only advantages, but also challenges. A great many researchers emphasized the positive effects of co-teaching on EFL learners and co-teachers as well (Keefe, Moore, Duff, 2004; Sturman, 1992; Sharma, 2017; Cook \& Friend 1995).

The US Peace Corps TEFL programme in Benin has utilized the co-planning and co-teaching model since 2011. Based on qualitative and quantitative methods, this paper explores how co-teaching is conducted in EFL classes in Benin, discusses its benefits and challenges, and makes suggestions on how to improve it. 
The Peace Corps has conducted an uninterrupted programme in Benin, from 1968 to the present, and its educational programme has had sustainable impacts on the country. The education programme was focused on primary education and sanitary education from 1974 to 1983 . Then in the 1980s, there was a great need for science teachers in the secondary schools and the Peace Corps education programme shifted attention in order to remedy the shortfalls in a number of subjects at both secondary and university levels. By 1979, education volunteers could be found intervening in higher education, teaching statistics, planning, management, and animal and vegetable agronomy. This programmatic focus remained until 1992. Based on Beninese government priorities, the education programme shifted its focus in 1999. Since that time, only TEFL volunteers have served in the education programme. Finally, in 2016, Benin welcomed its first group of TEFL Certificate volunteers. Presently, the TEFL Certificate Programme is a 30-month continuum of learning that provides over 120 hours of training and ongoing professional development with two years' supervised teaching experience to volunteers at selected posts. Upon a successful completion of the training and related assignments, the TEFL volunteers earn a certificate validated by the Centre for Applied Linguistics in Washington DC.

There is a problem of regional imbalance in education occurring in Benin. Although the same curriculum is used throughout the country, some regions are more privileged than others as far as the quality of teachers, education and socio-cultural context are concerned (Sekoubaou, 2017). In response, Peace Corps Benin tries to remedy these disparities by having TEFL volunteers serve in government schools in rural areas that are more in need of TEFL teachers and that require their service. Each TEFL volunteer has several weekly minimum requirements: that s/he teach three classes on his/her own, that's/he run an afterschool English club for two hours, that s/he contribute to the Community of Practice (CoP) by participating in the weekly department meeting and that s/he co-plan and co-teach for four hours per week with his/her counterparts. The school requesting a volunteer has to identify a motivated counterpart willing to collaborate with the volunteer but the volunteer also has to select a second English teacher counterpart. The underlying reason for co- teaching is to favour a sustainable skill transfer on both sides. The approach started in Benin in 2011 and has continued through to the present.

\section{B. The Purpose of the Study}

The main purpose of this study is to explore the concept and practice of co-teaching in public secondary schools in Benin. The researcher would also like to make the Beninese educational authorities aware of the necessity of changing the traditional teaching practices to co-teaching and making it an integral part of the current pedagogical practices in secondary schools. By doing so, Beninese EFL teachers who have not attended a teacher training college can develop and improve their basic teaching skills, and learn how to collaborate with peers in order to meet their learners' needs. Friend \& Cook (2006) support this idea by considering co-teaching as "a unique service delivery option that is based on collaboration". They added that "co-teaching is designed to meet educational needs of learners with diverse learning options." As this is an innovation of the Peace Corps TEFL Programme, most schools that do not request volunteers are unaware of this teaching strategy. This study can therefore be an important tool to spread this teaching approach. For that reason, the researcher intends to work closely with EFL teachers, teacher trainers, the Peace Corps TEFL programme staff and school authorities to evaluate the effects of co-teaching on team teachers and their learners. The researcher's intention is also to contribute positively, through this study, to the amelioration of the EFL teachers' professional development and the teaching and learning of English as a foreign language in Benin (Sekoubaou, 2017).

\section{Research Questions}

a) What type of co-teaching model is used in Beninese secondary schools?

b) What are the benefits and challenges of the style of co-teaching used in Beninese secondary schools?

c) How can co-planning and co-teaching in Beninese secondary schools be improved?

\section{LITERATURE REVIEW}

\section{Review of Research on Co-teaching}

Many researchers have addressed the concept of co-teaching in the EFL context from various angles. Their focus points have been the following: co-teaching terminology, the styles/forms of co-teaching, and specificities related to the countries of research.

\section{Defining Co-Teaching}

A review of literature in the field of co-teaching indicated a myriad of definitions. Jang (2006) and Carpenter et al., (2007) used the terms "collaborative teaching," "team teaching," "co-enrolment," and "cooperative teaching" interchangeably. Overall, some scholars defined it as a collaboration among primary school teachers (Golner \& Powell, 1992). They elaborated further on the concept to demonstrate that collaboration is a long process that takes time to be developed and maintained. To come to a good collaboration, trust and mutual understanding are required. For Head $\&$ Taylor (1997) and McLaughlin, (1997) when the collaboration is successful, it enables team teachers to learn from each other and increases opportunities for their professional development. Davis (1995) offered a more complete definition by including planning and lesson implementation; for him co- teaching is "all arrangements that include two or more faculty in some level of collaboration in the planning and delivery of a course". Quinn \& Kanter (1984 as cited in CELT, 1998) and Goetz, (2000) added the concept of evaluation to the definition. For them, co-teaching involves a group of 
instructors collaborating together to "plan, conduct, and evaluate the learning activities of the same group of learners." For Crow et al. (2005) as cited by Brody (1994), we cannot talk of co-teaching without mentioning the learning community it helps to create. They advocated for the idea of a more inclusive concept of co-teaching. For them, "coteaching involves two or more teachers planning, teaching and assessing the same learners in the interest of creating a learning community and maintaining a commitment to collaboration with learners and each other." Cook \& Friend (2016) put emphasis on the co-teachers' qualifications, stating that they should be certified professionals, work together, share responsibilities and be equally accountable for their performance. Obviously there is one agreed upon definition of co-teaching; each expert simply improves on the definition by including new ideas. Two of the major elements that are repeatedly echoed in the definitions are "working together" and "collaboration." Collaboration is vital for effective co-teaching; it flourishes when everyone understands that even though each of us is unique, we can collaborate, unite our strengths to generate great ideas. Scholars from various disciplines have cited one another's research and assessed the styles of co-teaching after experiencing them or conducting studies on them (Tsai, 2007; Jan, 2006; Sharma, 2017; Carley III, 2013; Liu, 2008; Abernethy, 2017). They even explored the transferability of co-teaching models and strategies from one discipline to another. This interdisciplinary collaboration is emphasised by Walther-Thomas (1997).

\section{Describing the forms of co-teaching}

This section sheds light on the first research question. Theorists identified several models of co-teaching (Goetz, 2000; Martinsen, 2004; Bacharach et al, 2008; Honigsfeld \& Dove, 2008; Jang, 2006; Day \& Hurrell, 2012; Abernethy, 2017;). Six co-teaching styles are frequently used in EFL/ESL context:

(1) One teaching, one observing: this is a technique in which one teacher conducts the instructions while the other observes. Before the observation, co-teachers agree on the data to collect during the observation and the necessity of giving specific critiques; co-teachers agree on the data gathering system in order to avoid confusion and frustration during the data analysis that should take place after the observation. This approach is suitable for a student teacher since it enables him/her to learn while observing.

(2) One teaching, one assisting: this approach is also known as one teaching, one drifting; with it, one teacher takes the lead for the primary responsibility for teaching while the assisting teacher provides help as s/he circulates in the classroom. His/her primary duty is to help learners who struggle with understanding instructions or directions. In this situation, the supporting teacher may retell parts of the lesson, or rephrase directions. Preferably, the leading teacher and the supporting teacher alternate roles, which is why it is important to co- plan so that one teacher doesn't find him/herself in a subordinate role.

(3) Station teaching: the room is arranged in stations; each teacher delivers a portion of the content information to small group of learners who work on assignments and rotate through the stations; there may be a third station that gives opportunity to learners to work independently.

(4) Parallel teaching: this is an approach for which two teachers co-plan the lesson. Each of them has a lesson plan with the same content information that they deliver simultaneously to two different heterogeneous equal groups of learners. Learners have the advantage of benefiting from more supervision time, and more opportunities for interaction. Even though co-teachers may have different teaching styles, they can still work together and monitor learners' progress.

(5) Alternative teaching: this is characterised as "a classroom of one larger group and one smaller one." The small group is made up of learners who may require specialised attention. The main instruction is provided by one teacher to the whole group while the other teacher works with the small group on predetermined area. Due to this arrangement, however, the class is sometimes chatty.

(6) Team teaching: this is the most complex and challenging co-teaching approach since it requires trust and honest collaboration. It requires team teachers to co-plan the lesson and each team teacher has a lesson plan with the same content information. This way, the roles and responsibilities are equally shared in the classroom (Cook \& Friend, 1995). Both teachers are actively involved in the lesson delivery in such a way that no one really takes the lead. This approach is referred to as "one brain in two bodies" on the State Education Resource Centre website (2004).

\section{Co-teaching model used in Beninese secondary schools}

As previously stated, the Peace Corps education programme is a pioneer in co-teaching in the Beninese secondary school EFL classes. Two main styles are currently being used and Peace Corps TEFL volunteers are introduced to them during a practicum known as "model school." Model school is part of Pre-Service Training (PST), a three-week mandatory training that mocks the environment of a real-life secondary school in Benin. The first two weeks are dedicated to the "one teaching, one observing" style with the purpose of preparing volunteers to learn from one another and enhance their general teaching skills. The third week of practicum is devoted to "team-teaching" in unison with host country national teachers. It is worth mentioning that these teachers have to attend together with the volunteer a session on "co-planning and co-teaching." This style is used by TEFL volunteer throughout their service in order to build professional capacities in their communities.

\section{Researches on Co-teaching in EFL context}

A great number of researches were conducted to contribute to the literature on team-teaching in EFL context. Asia has the highest research record in this field. In qualitative case studies, targeting Taiwanese elementary schools EFL teachers, Tsai (2007) proved that having NESTs and NNESTs co-plan and co-teach greatly enhanced team teachers' professional growth. The researcher also pointed out some factors that stood as barriers to team teachers' good 
collaboration and prevented them from learning from each other. This research has similar results regarding Taiwanese EFL teachers' capacity building as compared to Benin. However, the downsides of team-teaching in Taiwan are quite different from the Beninese situation. In Japanese junior high schools, both public and private, Macedo (2002) investigated on team teaching, focussing on reverse style as opposed to traditional one. In reverse team teaching NEST carries out the primary responsibilities and the NNEST acts as an assistant. The study revealed that the reverse team teaching was more predominant in Japan and the NESTs or Assistant Language Teachers (ALTs) didn't like it because it put more workload on them. As compared to the Beninese EFL context, the two situations are completely different. Peace Corps TEFL volunteers are not viewed as assistant language teachers but as Beninese EFL teachers' colleagues. In the same vein of benefits of co-teaching, Honigsfeld \& Dove (2008) pointed out that co-teaching could help EFL learners meet national, state and local standards.

Team teaching also helps improve learners' language proficiency level; Baniabdelrahman (2013) confirmed that idea through a research conducted among Saudi Arabian first year university students co-taught by a combination between NEST and NNEST. Liu (2008) found out that co-teaching involving NEST and NNEST in Chinese primary schools was beneficial to co-teachers because both of them improved on their teaching quality. The researcher suggested four co-teaching models to be used sequentially in order to help NEST build up their co-teaching skills progressively. Even though this context is also an EFL one, the main difference with Benin lies in the fact that the co-teaching is implemented in the primary school and more than two models are used. Not all scholars viewed co-teaching as beneficial. Carley III (2013) found out through experiences and results from his research in Japan that team teaching didn't work. For him, students didn't benefit from team teaching due to conflicting relationships between team teachers. The good news is that Wang (2010) suggests some tips on how to effectively collaborate to make team teaching successful in EFL classroom.

\section{METHOD}

\section{A. Participants and Settings}

Thirty team teachers and administrative members from middle and high schools (28 middle schools and 2 high schools) in seven state departments ${ }^{1}$ (French départements) of secondary education out of the twelve existing departments (Atacora, Donga, Borgou, Zou, Collines, Mono, and the Plateau), participated in the study. Teams consisted of one TEFL volunteer with one or two EFL local teachers who play the role of the volunteer's counterparts and one administrative member, either the headmaster or the assistant headmaster who designs all the teachers' timetables. School teams were selected taking into account three criteria. First, the team teachers must be practising team teaching for two to four hours per week, have at least three months experience at the beginning of the study and be willing to participate. Second, all the potential teams were observed while co-teaching to first verify whether weekly coteaching was effectively practised and secondly to determine the style of co-teaching in use. Third, following observation, the teams were asked to be interviewed and to fill out a questionnaire. A total of one hundred participants (30 TEFL volunteers, 40 counterparts and 30 administrative members) participated in the study. Among TEFL volunteers, there were 7 males $(23.33 \%)$ and 23 females $(76.66 \%)$ and all of them were going through the TEFL Certificate Programme. Among the counterparts, there were 2 females (5\%) and 38 males (95\%); all of whom had academic degrees in the English language. For 8 teachers $(20 \%)$, this degree was coupled with a professional degree. $32(80 \%)$ counterparts were part-time teachers while the remaining $8(20 \%)$ were full-time teachers. All the administrative members were male (100\%). The age range for the PC TEFL volunteers and their counterparts was between 21 and 30 years old. Most of the administrative members were between 30 and 55 years old. During the 6month period there were no staffing changes and no participants changed schools.

\section{B. Data Source}

As there was no previous research on co-teaching in Benin, this research serves as a starting point that has the potential to inspire other researchers for their studies. This was why the researcher went to the field to collect data based on the participants' behaviour in their settings. By doing so, the researcher adopted the naturalistic inquiry methodology (Lincoln \& Guba, 1985) combined with a descriptive approach. The data was collected through three main sources: questionnaires, classroom observations, and interviews added to informal contact. Both qualitative and quantitative techniques were used for the study.

1. Questionnaire

A 10-item questionnaire in English was designed to collect data from EFL teachers involved in co-teaching; 70 respondents $(93.33 \%)$ out of 75 subjects who received the questionnaire returned it. The respondents co-taught in 30 different secondary schools, so the researcher interviewed one administrative member from each school. The collected data were compiled and analysed in terms of percentage and implication.

2. Classroom Observations

All the co-taught classrooms were observed in November 2016, as November 2017, the third month of the school year. School generally begins the last week in September or the first week in October in Benin. Each observation lasted

\footnotetext{
${ }^{1}$ Département: it is an administrative or political subdivision in Benin Republic; there are 12 departments.
} 
one hour. Trained Peace Corps staff collected the classroom observation data and interviewed the team teachers afterward. For classroom observations, the observers used two observation sheets. The first is a two-column document to record what the teacher and learners were doing, and on the second sheet, observers checked off the criteria depending on how often the co-teaching skills occurred during the lesson implementation. The collected data helped to determine the type of co-teaching used, as well as the personality and the level of collaboration of the team teachers.

3. Interviews and informal contacts

Individual interviews were conducted with the participants after the classroom observation. The interview session lasted 15 to 20 minutes. A 7- item questionnaire was designed to collect data on non-observable aspects regarding the EFL teachers and co-teaching approach. For example, teachers self- rated their general teaching proficiency skills, stated whether they enjoyed co-planning and co-teaching with a local or native English speaking teachers, and how they transferred their takeaways when they solo taught in their classroom, etc. Some questions were open-ended and additional inquiries were used to clarify answers provided by participants. The same procedure was used while conducting interviews with the school headmaster and their assistants. They were asked how they facilitated the coteaching while designing teachers' timetables and the kind of support they provided to the team teachers as supervisors. Relevant documents such as the "Cahier de textes"2 and the gradebooks were requested to confirm the information provided by school administrative members. The interviewer carefully audiotaped all the information collected from participants with their permission. Audiotaping allows to review the information in details and to grasp the message that might be long and complex.

Informal contacts consisted of telephone conversation, Peace Corps training events, and keeping in touch with the volunteers and their counterparts after the site visits. Actually, no formal data was collected through these different interactions. However, these informal contacts enabled the researcher to have a follow-up on the previously collected information and to be helpful to participants by suggesting strategies to cope with issues that might arise between the team teachers and the school administration. In the Beninese secondary schools, teachers' timetables can change at any time when a teacher is transferred from the school or a specific recommendation is sent from the hierarchy as the system functions on a top-down modality.

\section{RESUlTS AND ANALYSIS}

Data Collected with Questionnaire from TEFL Teachers and Their Analysis

The provided responses are grouped for analysis. Thus the responses for question N1 concerning the affiliated state department of secondary education is shown on figure 1 and 2 while questions N2,3,4, 5, 6, 7 are in table $1 \& 2$ and the responses for questions $8,9,10$ are dealt with separately.

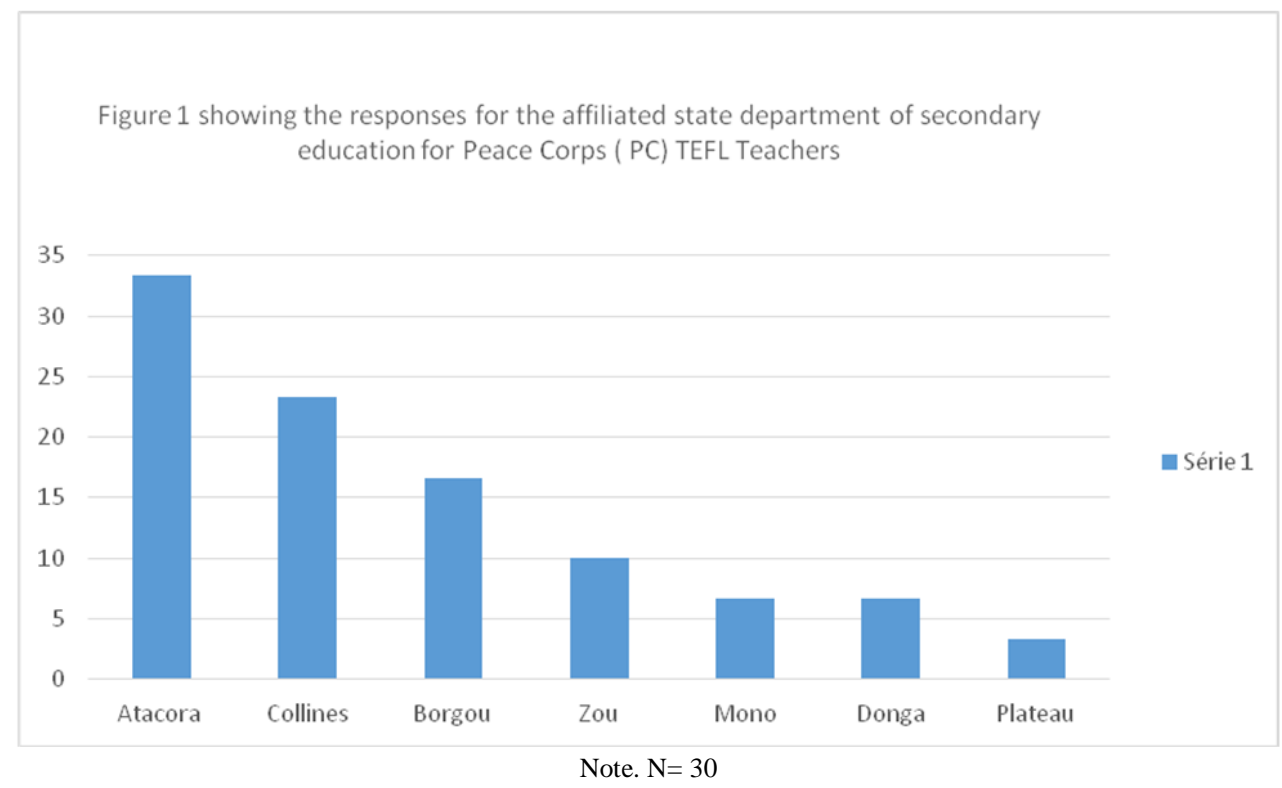

\footnotetext{
${ }^{2}$ Cahier de textes: a note book in which all the different school subjects teachers mention what they have taught to the learners at a given date and time.
} 


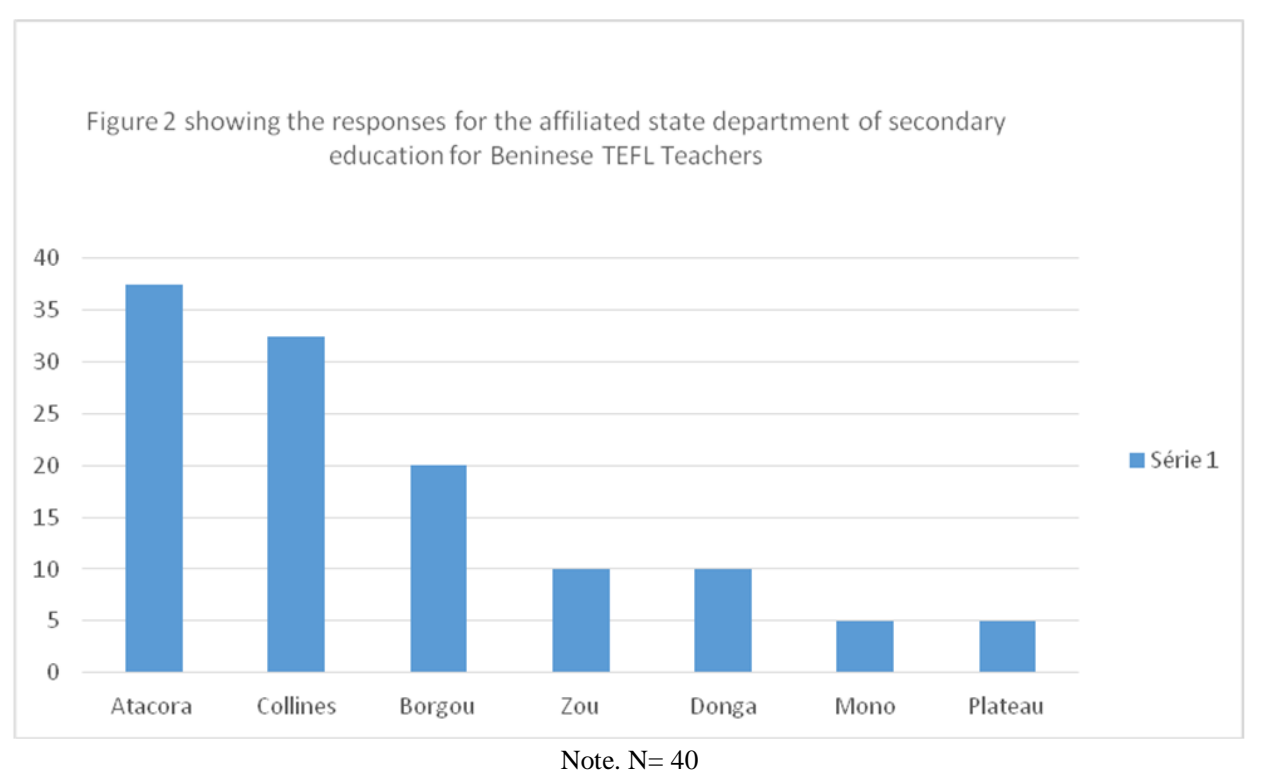

The northern state departments are Atacora, Donga, Borgou; the middle departments are Zou -Collines while Mono and Plateau are in the south. As indicated in figure 1 and 2, the state department of Atacora has the greatest number of PC TEFL volunteers and consequently the highest number of counterparts. This region of the country is increasingly in need of TEFL teachers and even though PC tries to fill in the gap, this does not cover all the existing needs. The number gradually decreases as it goes south to end up with $5 \%$ in the state departments of Mono and Plateau. Even though Donga is a northern department, it doesn't have many TEFL volunteers because schools do not request their service. This might be due to the fact that they do not know how to apply for a volunteer's service or they can't meet the housing requirement.

It is worth mentioning that Benin has had only one principal national university (National University of Benin -UNB changed to University of Abomey- Calavi- UAC) from 1970 to 2001 when a second one was created (University of Parakou- UP). The UAC is located in the Atlantic state department in the south and many learners from the northern regions can't afford the lodging and tuition in Cotonou. This is one of the reasons why there are few learners from the north who attended university to earn teaching degrees. The Government tries to remedy this regional unbalance in education by sending qualified teachers from the south to teach in the northern public secondary schools with incentives to encourage them to serve there. Unfortunately after a few years of service, those teachers often return to the south because it offers many more opportunities. Some of the reasons why civil servants want to serve in the southern regions include: teachers can complete a degree at university while working, they can also teach in private schools, they can do one -on -one home tutoring to learners and earn extra money, and they can connect with close friends and families. As previously stated, Peace Corps Benin works closely with the Ministry of Education to remedy the shortfalls in TEFL teachers. Peace Corps can't satisfy to all the demands in teachers due to the small number of TEFL volunteers who are sent to Benin each year.

TABLE 1:

RESPONSES PROVIDED BY PC TEFL VOLUNTEERS FOR QUESTIONS N2, 3, 4, 5, 6, 7

\begin{tabular}{|l|l|l|}
\hline Questionnaire statements & Responses & Number of respondents and \% \\
\hline Gender & male & $7(23.33 \%)$ \\
& Female & $23(76.66 \%)$ \\
\hline Age & $21-26$ & $29(96.66 \%)$ \\
& More than 26 & $1(3.33 \%)$ \\
\hline Qualification & Bachelor's degree & $30(100 \%)$ \\
EFL teaching experience & TAPIF ${ }^{3}$ & $1(3.33 \%)$ \\
& Online EFL/ESL Certificate & $2(6.66 \%)$ \\
& Master's degree & $1(3.33 \%)$ \\
\hline Which grade level do you co-teach? & First cycle & $28(93.33 \%)$ \\
& Second cycle & $2(6.66 \%)$ \\
\hline How long have you co-taught for? & 3 months & $20(66.66 \%)$ \\
& 6 months & 0 \\
& a year & 0 \\
\hline Whom do you co-teach with? & more than a year & $28(33.33 \%)$ \\
& a male teacher & $1(3.33 \%)$ \\
& a female teacher & $1(3.33 \%)$ \\
\hline
\end{tabular}


TABLE 2:

RESPONSES PROVIDED BY BENINESE TEFL TEACHERS FOR QUESTIONS N2, 3, 4, 5, 6, 7

\begin{tabular}{|l|l|l|}
\hline Questionnaire statements & Responses & Number of respondents and \% \\
\hline Gender & male & $38(95 \%)$ \\
& Female & $(5 \%)$ \\
\hline Age & $23-30$ & $37(92.5 \%)$ \\
& More than 30 & $3(7.5 \%)$ \\
\hline Qualification & Bachelor's degree in English & $39(97.5 \%)$ \\
& Two years of English studies at university & $1(2.5 \%)$ \\
& Professional degree & $8(20 \%)$ \\
\hline EFL teaching experience & 2 years & $2(40 \%)$ \\
& More than 2years & $38(95 \%)$ \\
\hline Which grade level do you co-teach? & First cycle & $38(95 \%)$ \\
& Second cycle & $2(5 \%)$ \\
\hline How long have you co-taught for? & 3 months & $25(62.5 \%)$ \\
& 6 months & 0 \\
& a year & $12(30 \%)$ \\
& more than a year & $3(7.5 \%)$ \\
\hline Whom do you co-teach with? & a male teacher & $7(17.5 \%)$ \\
& a female teacher & $33(82.5 \%)$ \\
\hline
\end{tabular}

Table $1 \& 2$ show that there are more female teachers $(76.66 \%)$ among the Peace Corps EFL teachers as compared to the $5 \%$ of Beninese ones. This poses the problem of gender in Beninese educational system. Girls' education has not been a priority for centuries in Benin, and girls are often denied access to education. Parents do not know the importance of educating their female children. Whenever they have the opportunity to send their children to school, they prefer sending boys. To remedy that disparity in Benin, the 1990 constitution states that "primary education shall be compulsory" and "the State shall progressively ensure that public education is free of charge" (Constitution of Benin Republic, December 1990). This constitutional decision was not applied until 1993 when girls in rural areas were exempted from tuition fees (cabinet meeting report, 1993). Currently there are no fees required in the primary school for both boys and girls. The exemption measure is extended to the middle school for girls. Nothing is concretely done to encourage women in higher education; that is one of the reasons why there are few female teachers in the secondary schools. Data presented in table $1 \& 2$ also indicated differences in the age range of teachers who co- teach. Peace Corps TEFL volunteers are younger than their counterparts; the majority (96.66) are between 21 and 26 while Beninese teachers' majority (92.5) are between 23 and 30. However, this age difference has less effect on the collaboration depending on the counterpart's personality.

As far as the team teachers' qualifications are concerned, both the Beninese teachers and the Peace Corps volunteers hold university degrees. All the TEFL volunteers were going through the TEFL Certificate Programme and already had six months of training ( 3 months for Pre-Departure and 3 months for Pre-Service training) before starting their teaching job. They have the necessary general teaching skills, they are qualified for the job and their teaching capacity will be strengthened through supervised assignments and classroom observations throughout their two years of service. The majority of Beninese teachers $32(80 \%)$ didn't go through a teacher training college before starting their job. However, the majority (95\%) have more than 2 years of classroom teaching experiences which far exceeds that of the Peace Corps TEFL volunteers, (3.33\% for TAPIF and 6.66\% for online ESL/EFL certificate). Moreover, the local teachers have the advantage of knowing the school system better, and knowing how the learners learn, but they are left to learn on the job on their own without formalised training. This is because there are no on-going training programmes developed for teachers. The learning- by- doing process is not often effective when there is no supervision. To remedy this lack of local teacher professional development, Peace Corps requires the counterparts to attend in- service trainings provided to PC TEFL volunteers so that the local teachers can be on the same page as their volunteers. Regarding the grade level where the co-teaching takes place, the majority of the team teachers co-teach in the first cycle grades. This is partly due to the fact that the PC TEFL volunteers teach from the sixth to the eighth grade. However, they can co- teach in any grade; this is why two $(6.66 \%)$ of them co- teach in the second cycle.

At the beginning of the survey, all the EFL teachers involved had at least three months of co-teaching experience which is one of the criteria to participate in the study. This enabled the respondents to provide valid information about co- planning and co-teaching. Twelve of the local teachers (30\%) had a year of co-teaching experience while $3(7.5 \%)$ had more than a year co-teaching experience. These three local teachers had the opportunity to learn and share coteaching experience with at least two TEFL volunteers and could assess the approach based on their experience. The majority of the local teachers $82.5 \%$ co- plan and co-teach with a female PC TEFL volunteers. Having male and female teachers is helpful to readily demonstrate some vocabulary words such as man and woman and possessive his/her, etc... it is also helpful for modelling positive and professional male/female relationships and behaviour.

\section{Impact of co-teaching on co-teacher, learners and on the curriculum}

\footnotetext{
${ }^{4}$ First cycle: from 6th to 9 th grade; second cycle: from 10th to 12 th grade
} 
It emerges from the data collected that co- teaching in Beninese EFL classrooms has a positive impact on team teachers, learners, and the curriculum. As the co-planning and co-teaching involves native English speaking teachers (NEST, PC TEFL volunteers) and non-native English speaking teachers (NNEST, Beninese EFL teachers), the combined strengths of both minimise the weaknesses and make the classroom instructions strong. NNEST know the educational culture well as they have been educated in it. They know how hard it is to learn English as a foreign language and when learners struggle with the content, they can be resourceful in the classroom. Most often NNEST know grammar rules better than NEST, so while co-planning NESTs benefit by raising their awareness about them. Gender equity in the classroom is an issue in Benin and the PC TEFL volunteers endeavour to make the local teachers become aware of it while co-teaching. The co-teaching helps Beninese EFL teachers to overcome their anxiety about English proficiency which prevents them from doing communicative activities involving more interactions among learners and turning their teaching into teacher-centred one. Generally, the team teachers learn from each other and help each other. It is also a great opportunity for novice teachers to develop professionally and enhance team spirit. It clearly shows that the approach is on win -win modality in Benin since the team teachers have a common goal which is to make their teaching effective and to grow professionally.

NESTs have a great value that they bring to the classroom which is the "communicative authenticity". In the Beninese context, learners do not have the opportunity to practise the language outside the four walls of their classrooms. This situation is against the idea of De Souza Miranda (2017) who thinks that" learners need opportunities to be creative and express themselves while learning a new language." If Beninese learners need to use English, it will probably be with someone from an English speaking country. So having NESTs teaching them is viewed as "accessible models", especially for pronunciation. Moreover, NESTs and NNESTs teaching together encourages Beninese learners to make efforts because when they hear NNEST speaking fluently and easily, they definitely think they can also do it. Learners are also exposed to a variety of teaching styles, different accents, and increase opportunity for learning since they receive more attention when there are two teachers. Learners also have more time for instruction and practice because co-teaching makes classroom management easier.

Co- teaching greatly enriches the curriculum in a number of ways. We cannot teach a foreign language without including the cultural dimension. NESTs co-teaching with NNESTs help create real-world context with specific language use; in short, they represent the lively culture of the target language in the classroom. The curriculum is also implemented with genuine and creative techniques designed as a result of the synthesis of the "two minds" cooperating together. Efficient time management is another positive aspect of co-teaching as team teachers act as "one idea in two bodies" make things move quickly. By so doing, more curriculum content is covered. Also, there are sometimes errors in the existing textbooks and NESTs help to fix them.

\section{School administration support to make the co-teaching successful}

Making co-teaching successful requires school administration support. From the data collected, school headmasters and their assistants have been making efforts to provide active support. Twenty- nine of them (96.66\%) helped to create a schedule that allows co-teaching, especially making sure it doesn't overlap with the counterparts' busy schedule. This high percentage is due to the fact that Peace Corps always organises a two day workshop to supervisors and counterparts prior to the service of PC TEFL volunteers in their assigned posts. It is a tight training module dealing with Peace Corps missions, goals, volunteers' service, tips to avoid creating frustrating situations, and how to provide adequate support when necessary. Five supervisors (16.66\%) reported having observed team teachers in their classrooms and provided constructive feedback. Three of them (10\%) also reported serving as mediators when there was problem related to the co-teachers' collaboration.

\section{Challenges related to co-planning and co-teaching in Beninese secondary EFL classes}

Discuss

As a quick reminder, Beninese adopt the team teaching approach; this strategy requires both teachers to cooperate, to co-plan since they have to deliver the same instruction at the same time (Abernethy, 2017; Sturman, 1992). It is not possible to team teach if there is no co-planning. The primary challenges to team teaching appear to be the time factor, counterparts' motivation and their availability. Most often and as aforementioned in the method, 32 (80\%) counterparts are part-time teachers. The recruiting process of part time teachers takes a lot of time and effort as their applications go through regional inspectors and teacher trainer office and consequently they often start teaching weeks and even months after the school has officially begun. Finding time in both team teachers' schedules is sometimes difficult, especially for Beninese teachers as they may have to teach one class at one school and then have to travel to another school that may be an hour or more away. Planning English time in their already busy schedule becomes a daunting challenge for school administrations and finding time to co-plan is also difficult. Wiltshire and Honma (1999) also came up with this time issue in their team teaching research pointing out that it is hard to find time to get together to talk about lesson. At any time the Ministry of Education can switch a teacher's school or combine two classes into one, which decreases the need of teachers.

The team teachers sometimes have differing approaches to lessons. The Beninese lesson plan format is in form of a chart more theoretical than practical. There are sections on competencies to be developed but teachers are not trained to design activities that are aligned to these competencies. They simply use existing materials (textbooks known as 
document d'accompagnement ${ }^{5}$ ) and don't offer opportunities to learners on how to think out of the box. Beninese teachers are good at teaching grammatical structures and most often would like to devote two hours lesson on them while the NEST would suggest supplementing the existing material with fun activities, and games. In such a situation, coming to consensus was somewhat hard. Some counterparts had their old lesson plans that they tried to substitute during co-planning. Even though in some cases, counterparts were diligent about co-planning, rewriting everything fresh, but while team teaching, they insisted on doing things their ways. As a result the talking time was not equally shared and one of the team teachers got frustrated.

Some Beninese teachers do not perceive the importance of gender equitable practices in teaching. Consequently, they were not willing to cooperate when the NEST suggested some activities to promote them. Most of the team teachers involved in the survey were made of a male teacher, 38 (95\%) for Beninese teachers and a female teacher, $23(76.66 \%)$ for PC TEFL volunteers. This caused some frustration among three female teachers (10\%) who expressed that their counterparts didn't take them seriously and were not interested in their ideas for their classes they co-taught. The learners in some schools, all regarded the male teacher as the "real" teacher and consequently only asked him questions, only went to him for permission to leave and the co-teacher couldn't understand why this was a problem.

\section{SugGESTIONS}

Team teaching in Beninese secondary school EFL classes offers both team teachers a great opportunity to grow professionally and to develop sound human relationships. To facilitate the collaboration, the team teachers should develop a relationship of mutual respect and trust right from the beginning so that they can support each other. PC TEFL volunteers have come to Benin to teach English and want to be respected and seen as someone who can make a contribution. In the same vein, Beninese EFL teachers have spent so many years to study English language and principles of foreign language learning and teaching and who want to be seen as someone who better understands how challenging it is to learn a foreign language. In such a context, even though each of the team teachers is unique and has one's own personality, they should make themselves useful, be extraordinary accommodating and open to collaboration to form a strong whole, using each other's strengths and covering each other's weaknesses in a creative way. Strong relationships are developed over time and when they come to maturity, they can make team teaching successful (Liu, 2008).

As most secondary schools in Benin have only male teachers, people culturally view the profession as a male driven one which is a stereotype. To remedy the situation it is important to train school administration members on the gender equitable practices and gender based challenges to improve the situation. Some efforts have been made regarding this but they need to be strengthened.

\section{CONCLUSION}

This paper has explored the concept and practice of co-teaching in public secondary school EFL classes in Benin. Up to now, the co-teaching has been conducted between the TEFL Peace Corps volunteers and their counterparts. The paper has discussed the benefits and challenges of the approach that is used. The advantages of co-teaching in the Beninese context include but are not limited to the professional development of the team teachers, cultural exchange, designing supplemental activities, introduction of new concepts such as gender equitable practices, and critical thinking in the educational system. Team teaching is not a panacea to all problems setting back Beninese educational system since it also has some downsides. The fundamental challenges with co-teaching have to do with teachers' personality, instability of part time teachers' job, and to a lesser extent the lack of incentive measures.

The implementation of team teaching in Beninese secondary schools is necessary because its advantages overweigh its challenges. The government needs to encourage the approach, work closely with the pioneering institution in order to generalise it to all public and private schools. The secondary school administrative members' scope of work should include the support to co-teaching by creating favourable schedules to team teaching, observing team teaching classrooms and helping solve conflicts that may arise between team teachers.

\section{APPENDIX A}

\section{TEACHERS' QUESTIONNAIRE}

Below is a questionnaire designed for the secondary school EFL teachers involved in Co-Planning and Co- teaching . It is designed with regard to explore the concept and practice of Co-teaching in public secondary school EFL classes in Benin.

Your answers will be confidential and your identity anonymous; moreover, the study will not report on individual schools. Thank you for your participation.

1- Name of school
2- Gender
3- Qualification : affiliated State department district office

$$
\text { Female }
$$$$
\text { Academic degree: }
$$

\footnotetext{
${ }^{5}$ Document d'accompagnement: learners' textbook
} 
4- EFL teaching experience

5- Which grade level do you co- teach? (please tick the appropriate box with regard to the level and cycle)

a- First cycle grade level

b- Second cycle grade level

6- How long have you co-taught for:
a- 3 months
b- 6 months
c- A year
d- More than a year

7- Whom do you co- teach with? A male teacher

8- How does the co-teaching impact

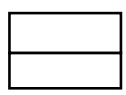
a- your co-teacher
b- your learners?
c- the curriculum

9- What administrative support can help to make co-teaching successful?

10- What are the challenges of co-planning and co-teaching in EFL classes in Benin?

\section{APPENDIX B}

Observation Sheet 1

Co-Teachers' Name:

School District

\section{Classroom observation comment}

a female teacher

both

Observe for an hour. Note what the teacher is doing and what the learners are doing. Mark the progress of the lesson increments of 20 minutes. Then tick the appropriate column on the observation sheet 2.

\begin{tabular}{|l|l|}
\hline What the teacher is doing & what the learners are doing \\
\hline 0 minute & 0 minute \\
\hline
\end{tabular}

Observation Sheet 2

Co-Teachers' Name:

School District

School:

\begin{tabular}{|c|c|c|c|c|c|}
\hline Co- Teaching skills & Never & Once & Sometimes & Often & Always \\
\hline Both teachers support and respect each other & & & & & \\
\hline Both teachers are consistent with the adopted approach & & & & & \\
\hline Co- teachers interrupt each other & & & & & \\
\hline Co- teachers share roles and responsibilities equally & & & & & \\
\hline The lesson delivery shows that the co-teachers plan together & & & & & \\
\hline Co-teachers are flexible & & & & & \\
\hline $\begin{array}{l}\text { Co-teachers develop tactful ways to give each other feedback when things } \\
\text { do not go well or when one makes a global error }\end{array}$ & & & & & \\
\hline One or both teachers was/ were angry, frustrated or upset & & & & & \\
\hline Co-teachers avoid misunderstanding due to cultural differences & & & & & \\
\hline $\begin{array}{l}\text { Learners' participation demonstrated they enjoyed being taught by the co- } \\
\text { teachers }\end{array}$ & & & & & \\
\hline
\end{tabular}

\section{APPENDIX C}

Interview questions to the team- teachers

1- Could you introduce yourself?

2- How do you rate your general teaching proficiency skills: fairly good- good- very good- exemplifying?

3- What do you most enjoy while co - planning and co- teaching with a native / local English as a foreign language teacher?

4- Are you satisfied with your relationship with your teaching partner? What do you foresee as a situation that may be detrimental to your collaboration? Do you think of any strategy to counter it?

5- Based on your observation, do you think your learners enjoy being taught by a local teacher and a Peace Corps volunteer? Could you give an example?

6- To what extent do you transfer your takeaways from co-teaching when teaching alone in your own classes?

7- What are your suggestions for improving co- planning and co-teaching in EFL classes in Benin? 


\section{REFERENCES}

[1] Abernethy, P. T. (2017). ESL Co-teaching: what works and what doesn't. Retrieved from https://www.wsfcs.k12.nc.us/.../ESL\%20Co-Teaching\%20Powerpoint\%20June\%202\% ... February 3, 2018 at $10 \mathrm{PM}$.

[2] Baniabdelrahman, A. (2013). Effect of team teaching and being the teacher native or non- native on EFL students' English language proficiency. African Educational Research Journal Published: July 22, 2013. Volume 1, Issue 2. Pages 85-95

[3] Carpenter, D. M., Crawford, L., \& Walden, R. (2007). Testing the efficacy of team teaching. Learning Environments Research, 10(1), 53-65. Doi: 10.1007/s10984-007-9019-y

[4] Carley III, H. F. (2013). Team teaching styles utilized in Japan: do they really work? Matsuyama University, Japan.

[5] Centre for the Enhancement of Learning and Teaching (CELT). (1998). Team Teaching. City University of Hong Kong. Retrieved from http:// teaching.polyu.edu.hk/datafiles/R27.html, January 15, at 3 PM.

[6] Cook, L., \&Friend, M. (1995). Co- teaching: Guidelines for creating effective practices. Focus on Exceptional Children, 28(3), $1-16$.

[7] Cook, L., \&Friend, M. (2016). Interactions: Collaboration skills for school Professionals, State Education Resource Center.

[8] Crow, J., \& Smith, L. (2005). Co-teaching in higher education: reflective conversation on shared experience as continued professional development for lecturers and health and social care students. Reflective practice, 6(4),491-506. Retrieved from http: //www. tandfonline.com /doi/ abs /10.1080/ 14623940500300582, January 30, 2018 at 9 AM.

[9] Davis, J. R. (1995). Interdisciplinary Courses and Team Teaching: New Arrangements for Learning. Phoenix, AZ: Oryx Press.

[10] Day, L., \& Hurrell, D. (2012). A teaching team: More than the sum of its parts. Teaching and learning Forum, Curtin University, Perth, Retrieved from http:// lsn.curtin.edu.au/ tlf/tlf2012/ refereed/ day.html, January 15, 2018 at 11 AM.

[11] De Souza Miranda, M., E. (2017). Evaluating Communicative Language by using Creative Dialogues, English Teaching Forum Vol 55, N4, p32-35, 2017.

[12] Honigsfeld, A., \& Dove, M. (2008). Co-teaching in the ESL Classroom. Delta Kappa Gamma Bulletin, 74(2), 8-14. Retrieved from http://www.nystesol.org/region/ArticleStudy_Co-teaching.pdf. Long Island RBE-RN - December 2017 at 2PM.

[13] Goetz, K. (2000). Perspectives on Team Teaching, a Peer Reviewed Journal, volume 1, Number 4, August 1, 2000. Retrieved from http:www.ucalgary.ca/egallery February 8, 2018 at 4PM.

[14] Golner, S. \& Powell, J. (1992). Ready for teaming: ten questions you ask before you jump in, Middle school Journal, 24 (1), 28-32.

[15] Head, K., \& Taylor, P. (1997). Readings in teacher development. Oxford: Heinemann.

[16] Jang, S. (2006). Research on the effects of team teaching upon two secondary school teachers. Educational Research, 48 (2), $177-194$

[17] Jang, Syh-Jong. (2006). Research on the effect of team teaching upon two secondary school teachers, Chung-Yuan Christian University, Taiwan.

[18] Keefe, E. B., \& Moore, V. (2004). The four "knows" of collaborative teaching. Teaching Exceptional Children, 36(5), 36-42.

[19] Lincoln, Y. S., \& Guba, E.G. (1985). Naturalistic inquiry. Newbury Park, CA: Sage.

[20] Liu, L. (2008). Co teaching between native and non- native English teachers: An exploration of co-teaching models and strategies in the Chinese primary school context, Yunnan Nationalities University.

[21] Macedo, Alan, R. (2002). Team teaching: who should really be in charge? A look at Reverse Vs traditional team teaching. A dissertation ... Center for English Language Studies. Department of English. University of Birmingham. Edgbaston, Birmingham B15 2TT. United Kingdom. March 2002.

[22] McLaughlin, M. W. (1997). Rebuilding teacher professionalism in the United States. In A. Hargreaves \& R. Evans (Eds), Beyond educational reform. Bringing teacher back in. Buckingham: Open University Press.

[23] Montgomery, M. \& Alamou, J. \& Dago, J. \& Gueye, A. \& Koffi, L. (1995). Go For English, Macmillan, EDICEF, 58, rue Jean-Bleuzen, 92178 VANVES Cedex.

[24] Sekoubaou, A. G. (2017). The Concept and Practice of Critical Thinking in EFL Classes in Benin: Prospects and Challenges. Studies in English Language Teaching Journal Vol. 5, N4, 2017. Pages 749-770.

[25] Sharma, G. G. (2017). Innovation and Co-teaching in Nepalese EFL Classroom, by NELTA Forum on July 2, 2017.

[26] Smith, M.K. (2016). 'What is teaching?' in the encyclopaedia of informal education. http:// infed.org/mobi/what-is-teaching/. Retrieved January 2018.

[27] Sturman, P. (1992). Team Teaching: A case study from Japan, Collaborative Language Learning and Teaching, Cambridge University Press, Nunan, D., 141-161

[28] Tsai, Jui-min. (2007). Team teaching and teachers' professional learning: case studies of collaboration between foreign and Taiwanese English teachers in Taiwanese elementary schools. Doctoral dissertation, school of the Ohio State University.

[29] Walther- Thomas, C.S. (1997). Inclusion and teaming: Including all students in the mainstream. In T. Dickinson \& T. Erb (Eds.), We gain more than we give: Teaming in middle schools (pp.487-522). Columbus, OH: National Middle Schools Association.

[30] Wang, D. (2010). Team Teaching and the Application in the Course English Teaching Methodology by CET and NSET in China. Jiaotong University. 88 West Anning Road Lanzhou Jiaotong University. 201 Mailbox, Lanzhou 730070, China. English Language Teaching Journal Vol.3, N 1, p87-91, March 2010.

[31] Wiltshier, J. and M. Honma. (1999). Action research: Semi-scripted monologues in team-teaching. JALT Publications, Dec. 1999: Language Teacher Online\# 2312. 
Gbènakpon, Abel, Sekoubaou was born in Adjarra, a suburb of Porto-Novo, the capital city of Benin Republic, a French speaking country in west Africa. He grew up and went to school in Benin where he earned a secondary school teacher's diploma from the teacher Training College in Porto-Novo in 2001 and a postgraduate diploma in TEFL in 2014 and he is currently a $\mathrm{PhD}$ candidate at Abomey-Calavi University in Benin Republic.

He has eighteen years of French and English Teaching experience under his belt and experience in adult teaching as well as training of language teachers. From 2004 to 2016, he has been a regional English as a Foreign Language Teachers' Advisor and Trainer in Atacora, a northern State Department of Benin and has about sixty EFL teachers to train. In 2006, he participated in the seminar on Local Educational Administration (Sub-Saharan African Countries) II at Sapporo City Board of Education organized by Japan International Cooperation Agency under the International Cooperation Programme of the Government of Japan. He joined US Peace Corps Benin in 2006 as a Language and Cross- Culture Facilitator and became Peace Corps Service Contractor in 2016 as the TEFL Certificate Coordinator. He participated in facilitation Boot Camp in Senegal in 2016 and in the TEFL Inter-Rater Reliability conference in Washington, DC in 2017. He is the author of "The Concept and Practice of Critical Thinking in EFL Classes in Benin: Prospects and Challenges", an article published by Studies in English Language Teaching Journal Vol. 5, N4, 2017. Pages 749-770. 